\title{
Highlighting supranational institutions? An automated analysis of EU politicisation (2002-2017)
}

\section{Tiago Silva, Yani Kartalis \& Marina Costa Lobo}

To cite this article: Tiago Silva, Yani Kartalis \& Marina Costa Lobo (2022) Highlighting supranational institutions? An automated analysis of EU politicisation (2002-2017), West European Politics, 45:4, 816-840, DOI: 10.1080/01402382.2021.1910778

To link to this article: https://doi.org/10.1080/01402382.2021.1910778

View supplementary material $₫$

\section{1.}

Submit your article to this journal $₫$

Џll Article views: 382

Q View related articles $\longleftarrow$

View Crossmark data $\nearrow$ 


\title{
Highlighting supranational institutions? An automated analysis of EU politicisation (2002-2017)
}

\author{
Tiago Silva (D), Yani Kartalis (D) and Marina Costa Lobo \\ Instituto de Ciências Sociais, Universidade de Lisboa, Lisbon, Portugal
}

\begin{abstract}
This article examines, using automated text analyses, the EU politicisation in the media of six Eurozone countries (Belgium, Germany, Greece, Ireland, Portugal and Spain), between 2002 and 2017. By contrasting creditor and debtor countries, the article analyses how the Eurozone crisis affected the politicisation of the EU and its institutions using a unique dataset of 165,341 articles from 12 newspapers. The results show that the Eurozone crisis increased the politicisation of the EU, particularly in the countries that were at the forefront of the Eurozone bailouts. Importantly, the crisis contributed as well to a more multifaceted news coverage of the European Union, namely with a greater emphasis given to supranational institutions vis-à-vis intergovernmental ones. Yet, this supranational coverage was associated with the increasingly negative tone of articles. To that extent, this study shows that greater mention of EU institutions may not necessarily contribute to a Europeanisation of public debates.
\end{abstract}

KEYWORDS European Union; politicisation; eurozone crisis; legislative elections; media coverage; automated text analysis

It has been well established that the deepening of the European project has made it more controversial among publics, altering the process of European integration from a permissive consensus to a constraining dissensus (Hooghe and Marks 2009). As increasing areas of public policy have become Europeanised in level and scope (Börzel 2005), parties began to contest this process (Marks and Steenbergen 2004), and citizens to polarise around the topic (de Vries 2007). This process of politicisation of the EU saw a turning point with the adoption of the Maastricht Treaty (Hooghe and Marks 2009), which constituted a structural deepening in European integration, with the creation of a political union, and economic and monetary union, among several other policies. As a result, since 
1992, the thereafter labelled European Union became a more salient and contested topic in the national politics of EU member-states.

From 2009 onwards, the EU was rocked by several crises, namely the Eurozone and the refugee crisis which rekindled the controversiality of the European integration project and brought the topic to the forefront of the political agenda (e.g. de Vries 2018; Grande and Hutter 2016a; Höglinger 2016; Hooghe and Marks 2018; Hutter and Kriesi 2019; Kriesi 2016). These existing studies, however, in part due to their different approaches and data used to measure the phenomenon, have not been completely in agreement.

This article sheds new light on the debate surrounding the magnitude of EU politicisation, and the impact of the eurozone crisis, by making use of a distinctive, and completely automated, method for measuring the salience and contestation of the EU in the media. This method, less costly and easier to replicate, opens the door to a more comprehensive understanding of the magnitude of EU politicisation and, when combined with other data, also its impact. More concretely, our results are relatively easy to be expanded to other countries and periods of time, maintaining high levels of comparability across time and across countries. Furthermore, our approach can be applied to any content available in a text-based format (e.g. social media, parliamentary debates) or to any topic henceforth. In this sense, the usefulness of this approach goes beyond the study of EU politicisation, offering as well an important tool for media studies and political communication in general.

We depart from previous studies of EU politicisation by not relying exclusively on political parties' EU statements but, alternatively, analysing all mentions of the EU. This allows us to bring forward other actors, besides political parties, in the measurement of EU politicisation. This is particularly important given the proliferation and significance attached to certain social movements during the Eurozone crisis, and even before that (Imig 2002), particularly in the bailout countries (Flesher Fominaya and Cox 2013). Our article is also innovative in showing the extent to which the EU's supranational or intergovernmental institutions are more mentioned as politicisation grows in different countries. This is important because an increase of supranational institutions' salience, in detriment of intergovernmental ones, may signal a more Europeanised public space.

We analyse both salience, tone and contestation of the EU topic in the print media of different Eurozone countries, in the context of national elections, from 2002 until 2017. Since the Eurozone crisis affected EU members asymmetrically, we study two distinct groups of countries: those who enjoyed relative prosperity during the period (Germany and Belgium), and those who suffered bailouts (Ireland, Greece, Spain and Portugal). Additionally, we analyse to what extent the EU has been reported in a multifaceted way, if that varies across countries and whether the Eurozone 
crisis impacted the salience of the main supranational and intergovernmental institutions of the EU. These comparative overviews are both informative about the extent to which the politicisation of the EU has played a role in national elections before and after the crisis, as well of the different narratives in debtor and creditor countries.

\section{The politicisation of the European integration process}

The idea of politicisation, defined by Schmitter (1969: 166), has become an essential hypothesis in the study of the European integration process, its expected outcomes and its impact on national politics. According to that author, politicisation refers to a process whereby a collective decision generates disputes, and wherein the audiences of those disputes gradually expand (Schmitter 1969). More recently, it has been defined as 'an increase in polarisation of opinions, interests or values and the extent to which they are publicly advanced towards the process of policy formulation' (de Wilde 2011: 559). Overall, despite some differences in the terms used, politicisation is divided into two elements. The first one, salience, concerns the expansion in the number of actors interested in a certain idea, which make it more visible. The second one, contestation, highlights the need for clashing preferences between the actors involved. These are two aspects that, when it comes to media news coverage, as suggested in Lippmann's seminal work of 1922, have often been positively correlated.

The politicisation of the European integration process has become a prolific subject of research, with a large body of literature examining how, especially since the Maastricht Treaty, contestation shapes the speed and direction of regional integration and impacts domestic conflict. In this regard, by attaching significance to public opinion, and challenging the idea of 'permissive consensus', the post-functionalist theory, proposed by Hooghe and Marks (2009), was a catalyst for EU politicisation studies.

Yet, extant research has been either inconclusive or contradictory (de Wilde and Zürn 2012; Green-Pedersen 2012; Hutter and Grande 2014; Statham and Trenz 2013). On the one hand, Green-Pedersen (2012) concludes, by looking at both media and party programmes in Denmark, that European integration did not go through an evident process of politicisation. Similarly, Höglinger argues that the EU politicisation has been limited, cyclical, and declining in the 2000s, a situation that the Eurozone crisis was unlikely to have changed (2016: 146).

On the other hand, despite not carrying out a longitudinal study, Statham and Trenz (2013: 169) find that the politicisation of the European integration process has been increasing. Despite some variation between 
countries and EU integration debates, Grande and Hutter (2016a) also find support for the politicisation hypotheses in a wide-ranging study of the press in six countries. These authors do not find, however, a clear linear trend of EU politicisation over the time, with the politicisation levels, in some occasions, being already high in the 1970s (Grande and Hutter 2016a: 87).

Despite not being strictly a 'post-Maastricht phenomenon' (Hutter et al. 2016: 281), the levels of EU politicisation seem to have been higher in the period around the Maastricht and northern enlargement (Grande and Hutter 2016a: 87). More recently, in a large-scale comparative study of the press, Hutter and Kriesi (2019) find evidence that the Eurozone and refugees crises contributed to the politicisation of the EU on a regional basis. While the Eurozone crisis increased the EU politicisation in the south of Europe, the refugees' crisis had a bigger impact in the North-western region.

Overall, most studies do not find evidence of a linear increase of EU politicisation since the 1990s. Contrarily, the high politicisation levels appear to be determined, on a punctuated basis, by anticipated (e.g. treaties) or unexpected (e.g. crisis) events. The majority of those studies rely on analysis of political actors' statements on media to measure EU politicisation (Höglinger 2016; Hutter et al. 2016; Hutter and Kriesi 2019), which is largely defined as a composite of salience and contestation of the EU dimension during legislative elections. However, the degree to which the media coverage accurately reflects the importance that political actors attribute to EU depends on certain media characteristics.

Indeed, the literature suggests that the news coverage of any topic, both in terms of its volume and content, can be dependent to some extent on aspects such as ownership (e.g. public versus private), type of media (e.g. television versus press), or the style (broadsheet or tabloid) of newspaper (Peter and de Vreese 2004; Pfetsch 1996; Nord and Strömbäck 2006). The European Integration topic, often perceived as more complex/technical (Kevin 2003; Statham 2007), is likelier to be discussed in the quality press and public broadcasting news (de Vreese et al. 2006). This visibility gap is particularly noticeable outside major EU events, where EU issues and actors are practically absent from the television news (Peter and de Vreese 2004; Pfetsch 1996). Not only the $\mathrm{EU}$ is absent in the media, it is predominantly reported in a neutral way (de Vreese 2003; Norris 2000).

In contrast to most existing media studies on the EU, we examine its impact during national election periods, rather than during EP elections or European referendums. This is an even more 'demanding' setting for the EU to matter since, as we know, Europe does not tend to be salient during EP elections, let alone national ones. Still, what we are interested 
in is in the salience of Europe and the consequences of that for national politics, and that is why our perspective is always about the national realm.

Moving beyond whether Europe has become politicised, current studies are starting to focus on the 'differentiated' forms it may assume (Braun et al. 2019). Among theorists of EU integration, there was a sense that Euroscepticism fed on 'constitutive' issues of membership and institutional design (Mair 2000), whereas, 'politicizing European policies' was likely to lead to a European public sphere (Risse 2010). Following this dichotomy between EU constitutive vs. policies issues, recent research has delved into EU salience in different types of texts (party manifestos, press releases) on these issues (Hutter et al. 2016; Senninger and Wagner 2015). A pattern is emerging among these studies, namely that (1) if you consider not only EU constitutive issues but also policies, EU salience is larger in any given political corpus of texts and (2) that mainstream government parties tend to focus on EU policy issues whereas extreme or opposition parties tend to focus on EU constitutive issues. These researchers' goals are to understand parties' strategies to cope with the EU issue, rather than media discourse, which is the goal of our article.

Therefore, we take on the idea of 'differentiated' politicisation but in the context of the 'Europeanisation of public debates' literature (Höglinger 2016; Pfetsch et al. 2008; Risse 2010). According to this literature, the greater the degree to which European actors are present in the European news items, the more conducive to a positive Europeanisation of national public spheres. They consider very important that European actors appear prominently in the news items about the EU because this would inform citizens about the importance of these actors in policy making, and make them more aware of the process of Europeanisation. Europeanisation can occur vertically, as national media extend their focus to include the additional level of government as political competences are shifted from national to European institutions, but also horizontally, to include coverage of other EU-member states (Koopmans and Erbe 2004). Recent studies on the Europeanisation of public spheres have shown that it is indeed occurring. Authors have shown that the emergence of a European public sphere is mostly vertical rather than horizontal, i.e. it is a process of 'segmented European public sphere' (Hepp et al. 2016; Kleinen-von Königslöw 2012). Using automated content analysis, Dutceac Segesten and Bossetta (2019) show that media articles about 'Euroscepticism' or 'Eurosceptic' are framed in a non-domestic (i.e. European) context, with the exception of the UK, where it is predominantly framed in a domestic context.

Research on the press performance allows us to contribute to this debate on whether the process of politicisation following the Eurozone crisis may be contributing to the formation of a European public sphere (Picard 
2015). This would be so, due to the fact that the media is conveying to the readers the importance of the EU institutions for economic policy making. As suggested by Zürn (2016: 168), the rise of awareness (i.e. the knowledge of the different institutions and the decisions made by them) is an important, but overlooked, component of the politicisation concept.

The period from 2009 onwards, which is characterised by debates on the Eurozone, may bring the seed of a European polity if it also includes mentions of European institutions, especially supranational ones. The Eurozone crisis led to the empowerment of certain supranational institutions such as the ECB, or the troika, through further steps to 'solve the crisis' (Leupold 2016; Schimmelfennig 2014). Thus, we go beyond the identification of an EU scope, to distinguish between whether news items discuss the EU, the EU supranational bodies, or the EU intergovernmental bodies. We focus on salience, contestation and tone of the EU longitudinally, to understand whether the eurozone crisis made a difference to these trends in the media during national elections in both debtor and creditor countries, and if the (rise in) politicisation was also accompanied by more referrals to specific EU actors over time. Contrary to other research, we distinguish between supranational and intergovernmental EU actors in order to assess whether the EU media discourse is being politicised towards an intergovernmental or supranational perspective on Europe.

Finally, given the state of the art on politicisation and the Eurozone crisis, it is important to explain the reasons for measuring its magnitude since entry into circulation of the Euro (2002), until the end of crisis (2017). Indeed, the introduction of the euro marks an important watershed in the daily presence of 'Europe' in citizens' lives, which suggests a salience of the European integration process at the national level, given the centrality of economic issues in any polity for political competition. Additionally, taking into account that crises are important moments to raise any issue's profile, we aim to map the changes in Europe's politicisation before and after the Eurozone crisis. The impact of the crisis on citizens' attitudes and behaviour is often assumed rather than demonstrated. By measuring the increase in politicisation of the EU, it becomes possible to link it directly to changing voting choices (Lobo and Pannico 2020). Our case selection ensures that we are able to test whether the asymmetric nature of the crisis was also reflected in the politicisation of the EU.

\section{Argument and expectations}

Our argument is that the evident deepening of European integration witnessed a turning point, for Eurozone countries, after the European Monetary Union was instituted. Given the supranationalisation of 
monetary policies in those countries, the onset of the Eurozone crisis created an ideal context for the politicisation of the EU. Thus, we test three expectations regarding the impact of the crisis in the media coverage of the EU dimension during national elections.

The first expectation is that, following the Eurozone crisis, the EU increased its salience and contestation in all of the EU countries analysed. Yet, we know that the crisis was asymmetric, with only some countries having to implement severe bailouts to rebalance their public finances and capitalise banks, therefore experiencing more intensively the crisis. Thus, our second main expectation is that there should be unevenly bolstered politicisation - with bailout countries observing, comparatively, higher levels.

Our third expectation derives from the premise that the Eurozone crisis also led to the empowerment of certain EU supranational institutions (Schimmelfennig 2014) and the creation of a European public sphere (Picard 2015). In this sense, the role played by those institutions amid the crisis might also have contributed to a more differentiated news coverage of the EU. In that case, we should expect more mentions of its different institutions, in a sign of openness of the public debates that includes a more diversified set of European actors. Therefore, our third expectation is that, after the Eurozone crisis, the salience of both supranational and intergovernmental institutions of the EU increased at the expense of the salience of the European Union as such.

Regarding the magnitude of EU politicisation, there are other differences that we should observe between the six countries analysed. Germany, which is the most studied case, has consistently shown moderate levels of politicisation (Grande and Hutter 2016b; Höglinger 2016). Within the debtors' group, Spain seems to be an exception, with a comparatively lower salience of the EU after the crisis being attributed to the timing of elections and party strategies (Hutter and Kriesi 2019). Indeed, party-level polarisation of the EU seems to have remained, even after the crisis, comparatively low in Spain (Goldberg et al. 2020). Finally, Belgium, with a language-divided media landscape, has never been included in comparative assessments of EU politicisation. As a founding member with a privileged/geographic connection to the EU, Belgium is therefore also an interesting case to analyse.

\section{Creating the text dataset}

This article analyses the news coverage of the press before the legislative elections of six EU member-states (Belgium, Germany, Greece, Ireland, Portugal and Spain) from 2002 until 2017, thus covering the campaign 
period of 29 elections. This allows us to include, for each country, elections before and after the Eurozone crisis. We analyse the press which has been frequently used as proxy to countries' media coverage since they always worked as the reference, when it comes to agenda setting, to other media (Boomgaarden et al. 2010). Two quality/broadsheet newspapers, with comparatively high readership, were selected for each country. Not only because these newspapers are likelier to deal more extensively with the EU topic, compared to tabloids, but are also likelier to setting the agenda. Based on existing media expert surveys (Popescu et al. 2011), we selected a newspaper from the left and right. For Belgium, a French and a Dutch-speaking mainstream newspaper were chosen. ${ }^{1}$ All items from the main sections ${ }^{2}$ of the newspapers were collected from the 30 issues published before each election, which corresponds to the period established for the official campaign in the majority of EU countries (Swanson and Mancini 1996: 259-60).

For newspapers only available in physical/paper formats, additional steps were taken to transform the articles into a machine-readable format. After scanning the newspaper, we used Optical Character Recognition (OCR) software to manually extract the title and body of each article into an excel sheet. Additional checks and cleaning were conducted due to the use of the OCR. ${ }^{3}$ The final dataset includes 165,341 newspaper articles.

\section{Methods for automated measurement of salience and contestation}

Similar to the previous media-based assessments of EU politicisation, we adopt a multidimensional concept of politicisation (de Wilde et al. 2016; Schmitter 1969) that focus on two attributes that need to occur: salience and contestation. However, we depart methodologically from previous studies by measuring those attributes in a computer-assisted way. This approach has two advantages that allow us to overcome some limitations of the existing comparative studies relying on extensive human coding. The first one is facilitating immensely the replication of the results and expand them to other countries and periods of time. This method is less expensive/time-consuming and offers an objective/quantitative comparison across countries and periods of time, that can become determinant to understand some consequences of the politicisation hypothesis.

The second advantage is that our approach offers a more encompassing, and in a way alternative, analysis of the EU politicisation. For practical reasons, the existing studies of politicisation in the media (e.g. Höglinger 2016; Hutter and Kriesi 2019) restrict the analysis to certain elite/collective actors (mainly political parties), type of articles (specific 
newspaper sections), and portions of text (title and lead/first paragraph). That approach, of considering the media mainly a data source (de Wilde et al. 2016: 8), not only makes their measurements vulnerable to differences and over-time changes in journalistic styles/preferences (e.g. reporting polarizing/controversial statements at the beginning) but also excludes a multitude of relevant actors that intervene in the debate about the EU. Thus, we follow in the tradition of Pfetsch et al. (2008), who are more interested in the media as a political actor, or a non-neutral debate setting (de Wilde and Lord 2016), influencing the Europeanisation of public debates per se.

By analysing EU politicisation in a broader sense, our method accounts for the expansion and diversification of actors concerned with the EU dimension. This is the most important difference and, therefore, our findings should complement, not challenge, the existing comparative assessments of politicisation. While the 'nuclear-sentence' coding approach (e.g. Höglinger 2016) focus on the salience of the EU dimension for certain key actors reported in the media, the article based approach (Schmidtke 2016), that we use, explores the overall politicisation of the EU in the traditional media landscape.

There are, however, some limitations in the computer-assisted analysis. First of all, the usefulness and accuracy of the method requires a systematic and large collection of newspaper articles, in a machine-readable format, which can be problematic in some cases. It also depends strongly on the development, and progress, of third-party tools. Therefore, the scope of the analysis that can be done with automated text-analysis is still far more limited than with the manual coding. It is nevertheless suitable for the concrete purposes of this study.

We operationalise salience, similarly to Schmidtke (2016), as the percentage of articles 'about the EU' in each newspaper, for each election/ year. We measure it using an extensive list of EU-related strings, ${ }^{4}$ adapted from the codebook of Maier et al. (2014), and translated in seven languages. Using the same approach as Maier et al. (2014), an article was considered 'about the EU' if any EU keyword appeared once in the title or twice in the article. From the 165,341 articles analysed, 22,769 mentioned the EU and 12,716 could be considered 'about the EU, ${ }^{5}$ corresponding, respectively, to $13.8 \%$ and $7.7 \%$ of all articles.

Compared to the salience of a certain topic in the media, the use of automated techniques to measure contestation is a far more complex task. In this paper, a sentiment/tone analysis approach to the articles mentioning EU was followed. Sentiment analysis is a well-developed approach to automated text analysis in the effort to derive meaning from text. It is a computational linguistics process that aims at extracting the opinion or the tone of a text by means of natural language processing 
(Pang and Lee 2008). Its applications to political science have tapped onto media tone (Soroka et al. 2015; Young and Soroka 2012), agenda setting (Ceron et al. 2016), framing (Burscher et al. 2014), and legislative debate (Proksch et al. 2019). The majority of these studies approach the task of automatically extracting sentiment from text either with sentiment dictionaries (e.g. Young and Soroka 2012) or with the use of machine learning (Burscher et al. 2014; Ceron et al. 2016).

In spite of its broad use in research, the vast majority of scholarly work utilising sentiment analysis has applied its methods on English-language texts. The corpus in this paper consists of six countries and seven languages. Building multiple annotated training datasets by means of manual coding for every article would be very expensive/ unpractical. At the same time, there is a lack of validated multilingual political science lexicons covering our use cases. Consequently, what is required in this case is a multilingual lexical sentiment analysis that bridges the language gap between lexicons and texts.

There are two possible approaches to this task, namely translating all the texts into a single 'pivot' language (Lucas et al. 2015), or bringing the lexicon items to the cases, by translating lexicons into each language of each text (Proksch et al. 2019). As Araújo et al. (2016) show, translating the specific languages to English and then applying existing methods designed for the English language yields better results. Additionally, the translation of the lexicons prohibits more sophisticated tools measuring sentiment that were built around the English language like valence shifters. ${ }^{6}$ Consequently, we opt for the translation of the target texts, given how feasible it is nowadays to perform large-scale machine translation and assume that in this way we maintain a high confidence in the measurement device.

Overall, the first step to analyse the sentiment linked to the EU was, for each article in the dataset, to extract all sentences that mention the EU and translate them to English. The translation was performed using the $R$ package googleLanguage $R($ ), that gives users access to Google's translation Application Programming Interface (API) service. On the translated text and on a per article basis, we implement the sentiment algorithm provided by the package sentimentr() by Rinker (2019). The sentimentr() package allows for the application of dictionary lexicons on documents taking into consideration possible valence shifters, ${ }^{7}$ which is basically an augmented sentiment dictionary lookup. ${ }^{8}$ This means that expressions like 'not good' do not get positive scores attributed to them, or that 'extremely bad' receives a more negative score than if it was 'a little bad'. Two sentiment scores for each article are produced: one is the mean sentiment score of every EU sentence in its body and another is the sentiment score of its title (if the title includes a relevant EU term). 
The final sentiment score of the article is a mean value of those two scores, ${ }^{9}$ which gives equal weight/importance to the two components of the article. ${ }^{10}$

Based on the signal of the final sentiment score, we code each article as either negative or positive towards the EU. We do so because the direction (positive or negative) of the sentiment scores is far more objective and meaningful than the variation of its degree. The EU contestation in the media is measured by the proximity of the frequencies of positive and negative articles for each newspaper in each election/year. Contestation is higher the closer the frequency of negative and positive articles is. The contestation score is calculated by subtracting from 100 the absolute value of the difference between the percentage of positive and negative articles (after excluding articles with neutral score). The contestation score can range from 0 (no contestation, or high consensus) to 100 (high contestation, where positive and negative articles have the same frequency). For example, $75 \%$ of positive (or negative) articles in one year translate in a contestation score of 50 .

Nevertheless, we also account for the sentiment scores' degree of variation by looking at the tone of news coverage. This measure corresponds to the mean of the final sentiment score of all articles mentioning $\mathrm{EU}$ for each election, having the two newspapers equally weighted. We multiply this value by 100 to facilitate its visualisation and comparison.

Finally, we examine the salience of the different EU facet that were visible in the media. We do this by counting the number of articles that mention either the $\mathrm{EU}$ as a whole, one of its main supranational institutions or one of its main intergovernmental institutions. We do this by restricting the keyword list used to identify EU articles to the classification described in Table 4 (in the Online appendix). The salience of a particular facet corresponds to the percentage of mentions it received over the total number of mentions. Therefore, the sum of the three facets' salience score is 100 .

\section{Results and discussion}

Figure 1 shows the results of the automated text analysis for each country. ${ }^{11}$ The values of the two measures, for each year, are the mean of the values of the two respective newspapers. When it comes to the salience of EU in the media, all countries show an increase over the period analysed. For all six countries, the salience of the EU in the last election was considerably higher than in the first. Moreover, the salience of $\mathrm{EU}$ in the first election had relatively similar scores, ranging from $4.1 \%$, in Belgium, to $6.9 \%$, in Portugal. However, as expected, the effect of the Eurozone crisis (2009 onwards) in the salience of the EU was more perceptible in the group of debtor countries, particularly in the 


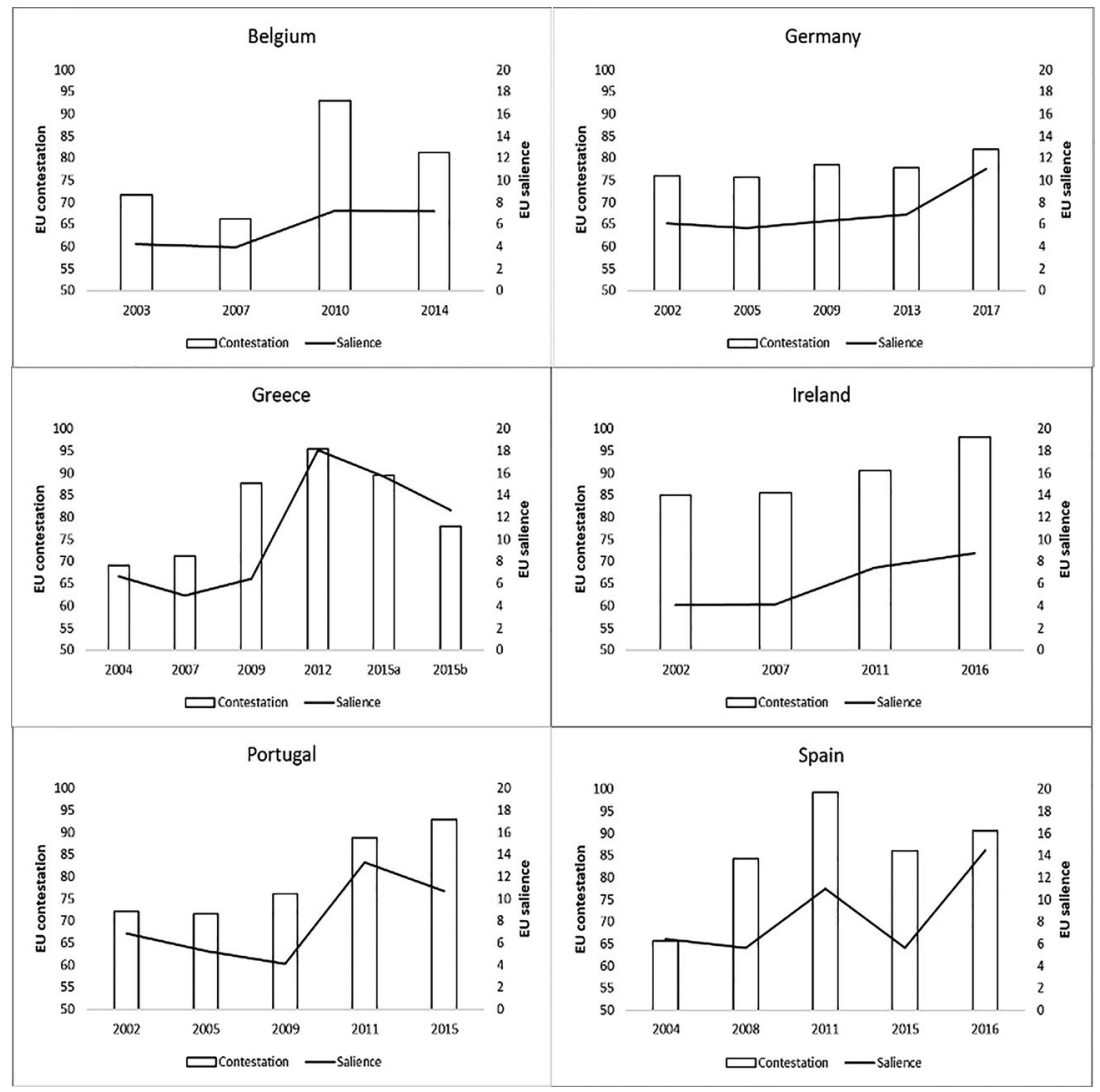

Figure 1. Salience and contestation of the news coverage of the EU made by the press during legislative elections in six Eurozone countries (2002-2017).

cases of Greece and Portugal. In those two countries, the visibility of the EU in the media practically tripled in the first election after their respective bailouts (2010 for Greece and 2011 for Portugal).

In the Greek case, the salience of the EU in the press went from $6.5 \%$ in 2009 to $18.1 \%$ in 2012 . Due to the crisis, Greece was the country, on average, with the highest salience of the EU (10.7\%), almost the double of Belgium (5.7\%), the country where the EU was the least salient. For Portugal, the salience of the EU in the media increased from a minimum of $4.1 \%$ in 2009 to a maximum of $13.3 \%$ in 2012 (the first election after the country's bailout). For these two countries, the results suggest that it was not the Eurozone crisis, but rather their respective bailouts, that increased the salience of the EU in the media.

The other two debtor countries, Ireland and Spain, had different developments regarding EU salience. In the case of Ireland, there has been, in the period analysed, a gradual increase of EU salience. In fact, out of the six countries analysed, Ireland is the only one where EU salience 
in the media always increased from one election to the other. However, unlike other debtor countries, Ireland did not show any evident effect of the crisis when it comes to EU salience. In this regard, Ireland has more similarity with the creditor countries.

In the case of Spain, differently from Greece and Portugal, it seems that it was the Eurozone crisis, rather than the actual financial bailout of Spanish banks in 2012, that stirred EU salience, increasing its value from $6.7 \%$, in 2008 , to $11 \%$, in 2011. Curiously, EU salience decreased considerably in the following election in 2015 (5.7\%) only to increase again the following year (14.5\%). This odd result in 2015 is particularly interesting considering that this election marked the collapse of the Spanish two-party system (Orriols and Cordero 2016). One could hypothesise that a shift of focus from the supranational to the national level in 2015 , clearly suggested here, might have also contributed to those radical institutional changes.

The two creditor countries observed, overall, a slow increase of EU salience in the media. In the case of Belgium, the most notorious increase happened between 2007 and 2010, while for Germany it occurred in the last election. Nevertheless, the maximum values of EU salience registered in these two countries were much lower than the peaks of salience observed in Greece, Portugal and Spain. Overall, differently from those three debtor countries, we cannot clearly observe, especially in Germany, an effect of the Eurozone crisis in EU salience. As we anticipated, our results also suggest that the EU has hardly been a salient issue during legislative elections in Germany. However, contrary to previous studies (Hutter and Kriesi 2019), when it comes to EU salience, Spain does not diverge from the other bailout countries. The fact that we find that the EU was indeed more emphasised in Spain with the crisis confirms the importance that non-party actors also have in the EU politicisation.

Regarding EU contestation, the story remains largely the same, confirming that, when it comes to news coverage of political issues, or any events for that matter, salience and contestation are positively correlated. ${ }^{12}$ In all six countries, the contestation of the EU topic has increased over the period analysed. Nevertheless, while that increase was relatively smooth in the case of Germany and Ireland, the other countries experienced, in some moments, much steeper increases of EU contestation. In all cases, the increase of EU contestation was driven by the increase of negative articles towards the EU.

In Greece, Portugal and Spain, there was a noticeable increase of EU contestation after 2008. While all of them had comparatively low levels of EU contestation before the crisis, the picture completely changed after 2008 as the proportion of articles with negative tone towards the EU increased considerably. This is particularly evident in the case of Spain where the 
contestation value ranged from the minimum of 65.6, in the first election, to the maximum of 99.2 in 2012. Curiously, in all three cases, the increase in contestation anticipated the increase in salience, suggesting that the media logic of attributing news value to conflict is a gradual process.

Looking at the tone of the articles in those three countries (Figure 2), we can clearly see that the EU was portrayed more negatively after the crisis, with the value becoming even negative in two occasions (Greece 2012 and Spain 2011). Even though it did not reach the low levels of Greece and Spain, Portugal is the only country where the tone towards the EU, since 2005, consistently declined from one election to the other. A final interesting aspect in the tone of the news coverage of Greece, Portugal and Spain is the fact that they had, before the crisis, the most positive news coverage of the EU.

Ireland is, again, an exception in the group of debtor countries. Not only did it have a flatter increase of contestation, but also the levels of EU contestation in Ireland were much higher in its first election, compared to the other countries. Since the EU contestation has always been relatively high, the results do not suggest a clear impact of the crisis in the contestation of the EU in the Irish mainstream press. Similar to what we observed in terms of salience, Ireland was the only country where the contestation value always increased during the period analysed. However, despite the smooth increase in salience and contestation, the overall tone towards the EU, as Figure 2 shows, had a considerable decrease in 2011.
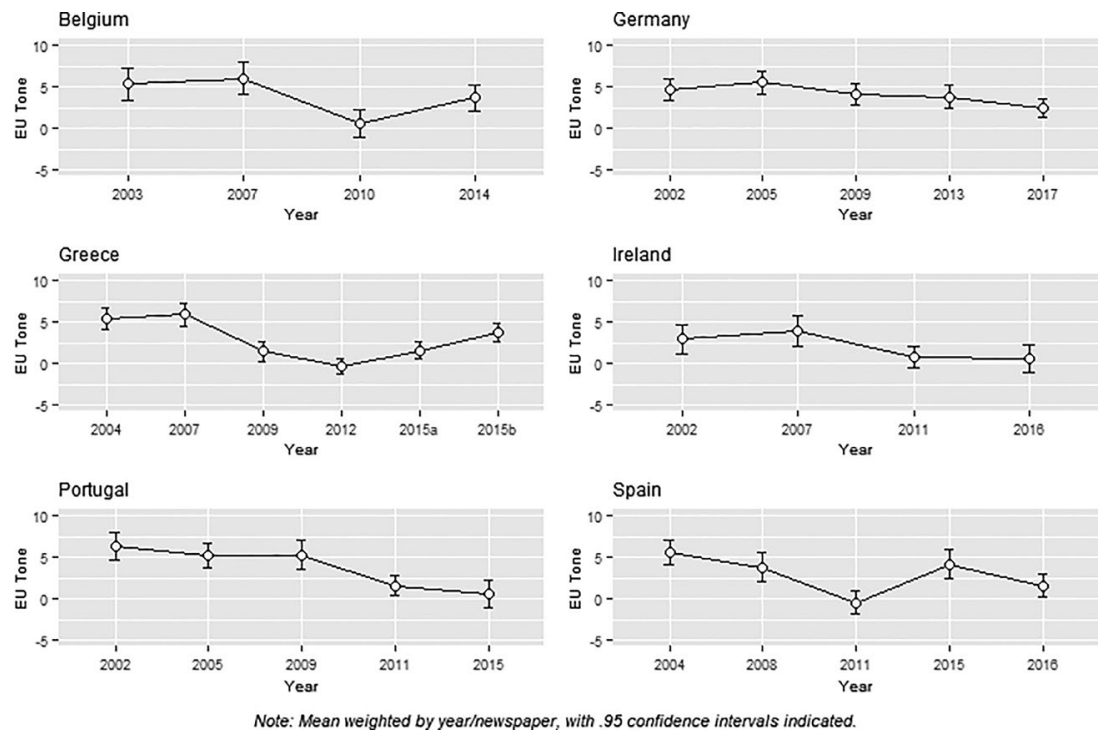

Figure 2. Tone of the news coverage of the EU made by the press during legislative elections (2002-2017). 
Finally, the two creditor countries have distinct stories when it comes to EU contestation. In this regard, on the one hand, Germany again tells us a story of apparent stability, where the levels of EU contestation did not vary considerably from one election to the other. On average, Germany had, from all six countries analysed, the lowest level of EU contestation and most positive tone towards the EU. On the other hand, Belgium had a sharp increase in EU contestation in 2010. This steep increase was accompanied by a noticeable decrease in the media's tone towards the EU, even though it did not lead, as we saw, to an equally significant increase of EU salience. The results suggest that the Eurozone crisis had an impact in the news coverage of the EU in Belgium, not necessarily increasing the politicisation of the EU topic, since it did not become particularly more salient, but by portraying the EU in a more negative way.

Overall, the results largely confirm our main expectation that the Eurozone crisis indeed affected the news coverage of the EU, during national elections, in some Eurozone countries. Similar to what Hutter and Kriesi (2019) found for the parties' campaign, the automated text analysis of media data also shows, during the Eurozone crisis, an increase in salience and contestation of the EU. However, the results also suggest, for all countries, a trend of growing politicisation in the media. Our method gives the possibility to investigate this possibility by further expanding the period of analysis. Furthermore, if we were to analyse each newspaper separately, the results would remain largely the same, ${ }^{13}$ which gives further robustness to our results and validation to the method.

The last aspect analysed concerns the EU dimensions discussed in the news coverage. The results, in Figure 3, give some support to our third expectation, suggesting that the Eurozone crisis indeed contributed to a comparatively higher salience of the EU supranational and intergovernmental institutions. After the crisis, the 'European Union' as a term was mentioned less often than before while its specific institutions were mentioned to a greater extent. Even though all countries show this trend to different degrees, Greece and Portugal are the clearest examples. In fact, in two occasions (the first Greek election of 2015 and the Portuguese elections of 2015), the salience of EU supranational institutions such as the European Commission and European Central Bank was higher than the salience of EU as such. The last election analysed does not seem to have changed this situation, suggesting that the Eurozone crisis might have had a long-lasting impact in the way that the European integration process is debated in these two countries.

For the remaining countries, two aspects are worth mentioning. Firstly, the intergovernmental institutions were practically absent in Germany. 


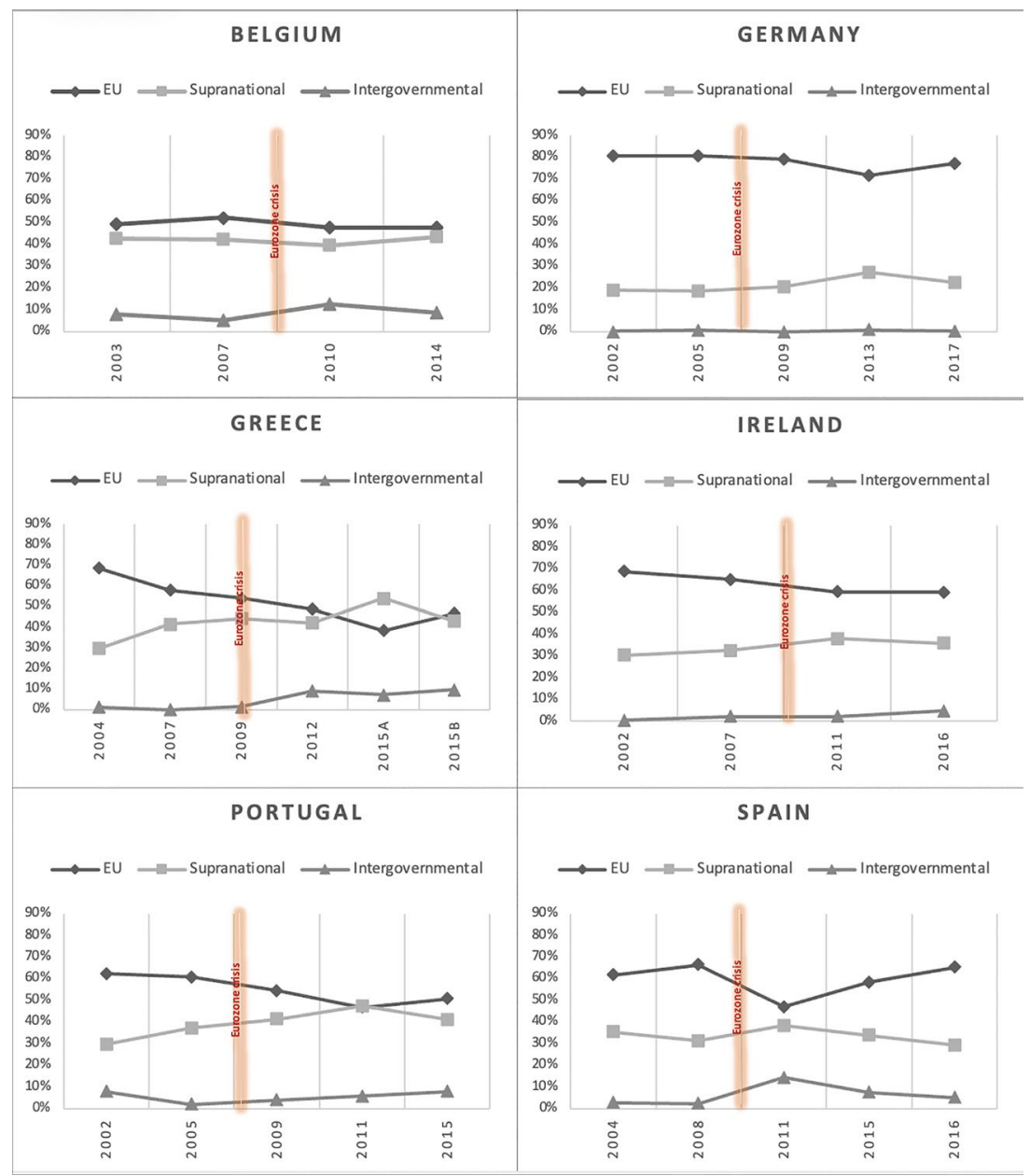

Figure 3. Salience of the three dimensions of the EU in the news coverage of legislative elections made by the press.

The EU media debate in Germany has been focussed on the EU as such rather than any other particular EU institution. The visibility of supranational institutions only slightly increased after the Eurozone crisis. Secondly, it is interesting to see in Belgium, despite the overall low salience of the EU, the consistently high visibility of the supranational dimension in the media.

Overall, when it comes to higher diversification in the news coverage of the EU, our results suggest that, to some extent, the Eurozone crisis indeed contributed to the Europeanization of the public debate. This was particularly evident in the cases of Greece and Portugal. In these countries, after the crisis, the supranational dimension became as salient as the EU, as such, in the media. 

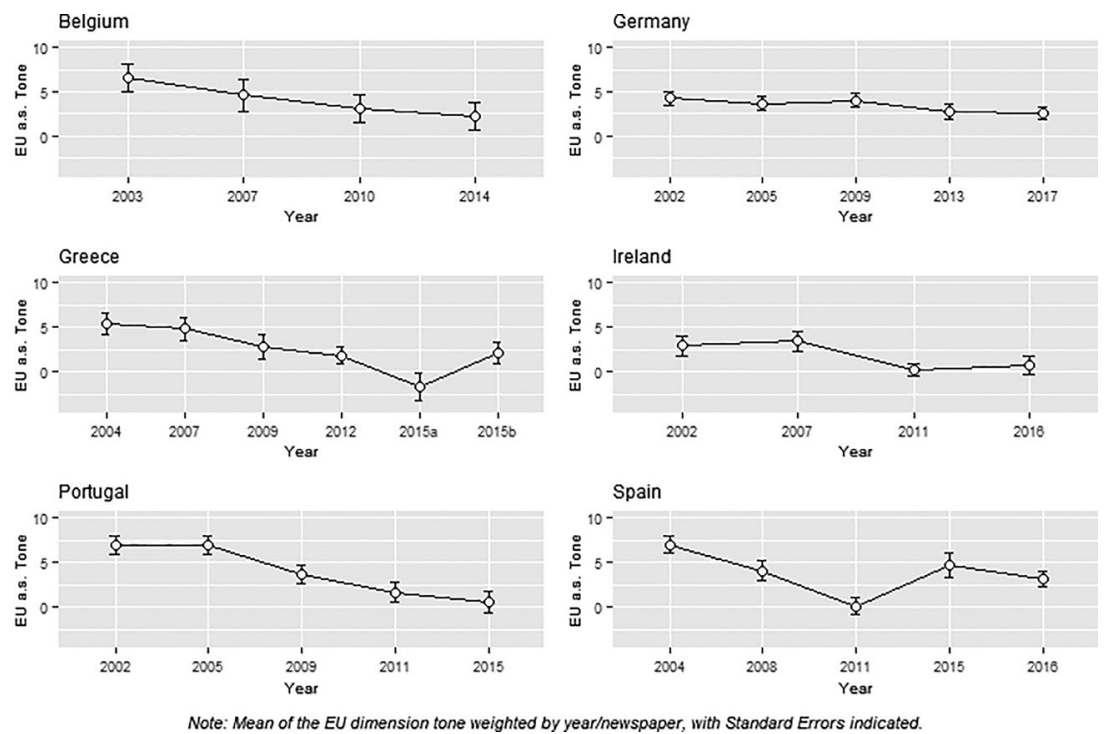

Figure 4. Tone of the news coverage of the EU dimension made by the press during legislative elections (2002-2017).

Finally, when it comes to media tone, the Eurozone crisis impacted the three dimensions of the EU differently. Figures 4-6 show the average tone of the news coverage of the three dimensions of the EU analysed (i.e. the EU as such, Supranational and Intergovernmental). While the results again show an increasingly negative media tone (or an increase in the proportion of negative articles) of the news coverage of the EU before and after the Eurozone crisis, they also suggest that this trend was more noticeable in the news coverage of the EU (as such) dimension. Moreover, the overtime increase of negativity of this dimension is evident in all six countries. In this regard, it was the first Greek election in 2015 that had the lowest value $(-1.7)$, while the most positive news coverage of the EU dimension occurred in the 2005 Portuguese election (7.0).

Concerning the supranational and intergovernmental dimensions of the EU, not only their overtime decrease in tone is less evident, but it also varied considerably on a country and election basis. However, we are talking about relatively small numbers of cases in some elections/ countries, particularly for the Intergovernmental dimension (see Table 7 in the Online appendix). Nevertheless, there are two interesting aspects suggested in the previous three figures that are well deserving of further investigation. One is the unusual pattern of the 2009 Greek election where low values of tone for $\mathrm{EU}$ and intergovernmental dimensions (2.8 and -1.9 , respectively) contrasted with an extremely positive coverage of supranational institutions (10.8). The second is the consistently more positive coverage that the intergovernmental dimension received. 

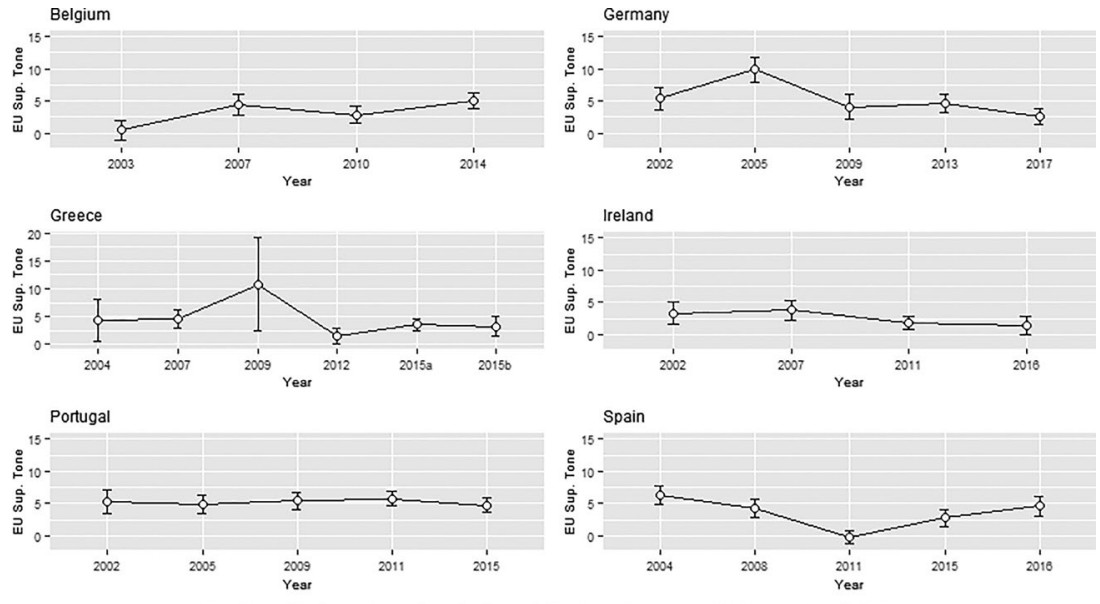

Note: Mean of the Supranational dimension Tone weighted by year/newspaper, with Standard Errors indicated.

Figure 5. Tone of the news coverage of the Supranational dimension of the EU made by the press during legislative elections (2002-2017).
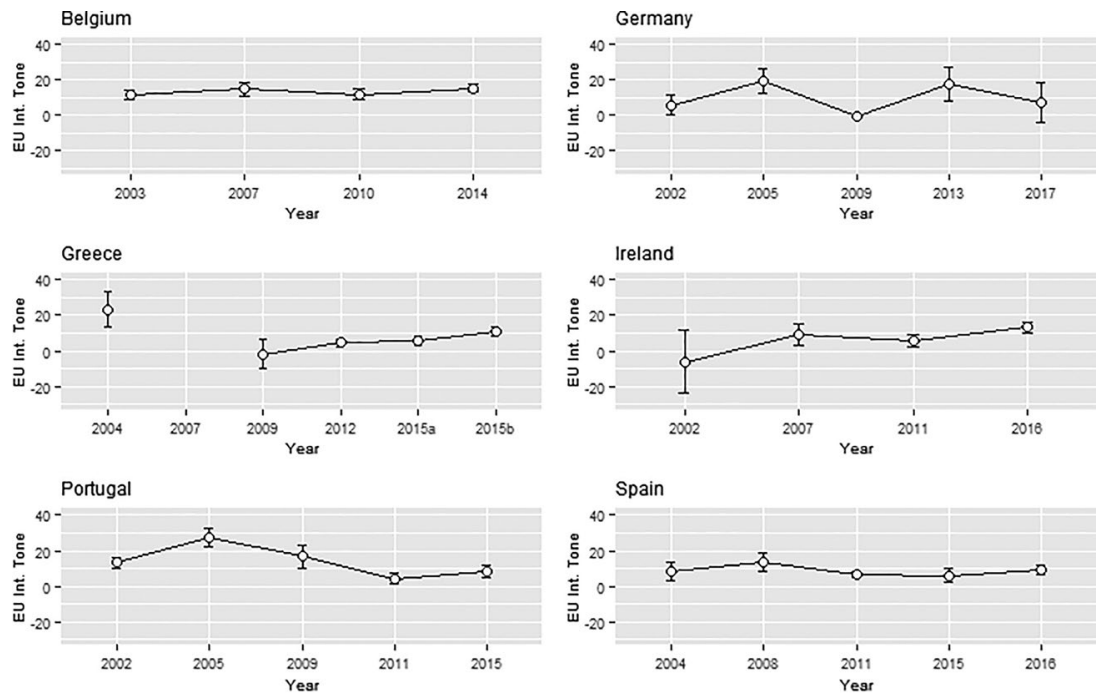

Note: Mean of the EU intergovernmental dimension tone weighted by year/newspaper, with Standard Errors indicated.

Figure 6. Tone of the news coverage of the Intergovernmental dimension of the EU made by the press during legislative elections (2002-2017).

A pattern that tends to be observed in all countries and in practically all elections.

\section{Conclusions}

This article set out to measure politicisation of the EU before and after the Eurozone crisis using automated text analysis. To that end, we follow existing literature in formulating three expectations. The first is that the 
politicisation of the EU would increase in all countries, following the onset of the Eurozone crisis. Second, that the increase in politicisation of the EU would be more pronounced in those countries which had undergone bailouts. The third is that the crisis tended to contribute to the increasing visibility of supranational institutions, which could signify a growing Europeanisation of public debates. We were able to confirm all three expectations to a certain extent. Namely, the average salience of the EU in the news media increased in all countries after the Eurozone crisis. Nevertheless, this increase was especially pronounced in the cases of Spain, Portugal and Greece. Ireland seems to be following a sui generis path, with greater proximity to the trends of Germany and Belgium. We also show that salience is closely correlated with contestation, and tone, towards the EU, which is important for the purposes of the concept of politicisation, and suggests that despite theoretical differences, they may not be so different in practice when considering mainstream news media.

Finally, we show that, with the exception of Germany, where supranational actors consistently do not seem too visible, and Belgium, where they always were, the crisis has been an opportunity for a greater openness of public debates to EU supranational institutions. In the context of national legislative elections, the public had at least the opportunity to become more knowledgeable about those institutions.

However, we also show that the supranational institutions are much more likely to be associated with negativity in tone than intergovernmental ones. Indeed, the intergovernmental dimension of the EU has been receiving, comparatively, more positive news coverage in the press: a situation that, differently from the EU and Supranational dimensions, was not altered with the crisis. This differentiation suggests that it may be simplistic to assume that mentioning supranational institutions is sufficient to promote Europeanisation, if these are more often mentioned in a negative tone.

This article's measures of politicisation are important to understand the mechanism through which citizens' attitudes and behaviours may be shaped by the media, and contribute to placing the $\mathrm{EU}$ at the centre of political debate. As our results show, going hand in hand with conflict and negativity, the visibility of the EU in the news media, crucial to inform citizens about the European integration process, does not come for free.

\section{Notes}

1. See Table 1, in the Online appendix, for a list of the elections and newspapers analysed for each country.

2. Only news items or opinion articles from the main sections of the newspapers were collected. Thus, pieces published in entertainment, culture, sports sections, etc., were excluded. 
3. Due to the use of OCR, some misspelling errors were occasionally produced. These errors were investigated by counting the percentage of unrecognized words in the articles, using a well-document/popular and free open-source spell-checking algorithm named UNSPELL for the automatic spellchecking. http://hunspell.github.io/. This process was implemented on a per language basis. Table 2 in the Online appendix presents descriptive statistics of the percentage of unrecognized words in each article's title and body. As we can see, the results were very low with a median of $5 \%$ of unrecognized words per article. The distributions of these percentages are identical for all newspapers and years. Note that an unrecognized word is not necessarily a misspelled word produced by the ORC extraction process. It can very well be that the word does not appear in the dictionary (e.g. abbreviations) or that it was already misspelled in the original document. In the end, a small number of articles, with more than $35 \%$ of unrecognized words in their body, were dropped from the dataset.

4. Table 3, in the Online appendix has the list of terms used.

5. See Figure 9 in the Online appendix for a comparison of the salience results using more exclusive rules.

6. Valence shifters are words in the text that alter or intensify the meaning of polarized words. They include negators (e.g. 'This movie is good' vs 'This movie is not good') and amplifiers (e.g. 'This movie is good' vs 'This movie is very good').

7. Popular dictionaries include general purpose ones like the Bing Lexicon $(\mathrm{Hu}$ and Liu 2004), the NRC Emotion Lexicon (Mohammed and Turney 2010), or the AFINN dictionary (Nielsen 2011). More case-specific dictionaries for political science include the LIWC lexicon (Tausczik and Pennebaker 2010) and the LSD (by lexicoder, tested in Young and Soroka 2012).

8. We do not claim that sentiment analysis based solely on word-by-word lexicon lookups or even including valence shifters is state-of-the-art. We also know that this approach cannot really compete with dedicated sentiment analysis techniques from the machine learning literature. However, for this particular use case of detecting broader latent patterns of sentiment in a large selection of texts, our goal is to build a reliable tool.

9. The results do not noticeably change using exclusively the score of the article's body (see Figure 7 in the Online appendix).

10. We summarize in Figure 8 (in the Online appendix) additional validation steps implemented for our measures of EU salience and contestation.

11. Table 6 (Online appendix) has the values for Salience, Contestation, Percentage of Neutral Articles and Tone for each election.

12. See Table 5 in the Online appendix.

13. See Figure 10, in the Online appendix.

\section{Disclosure statement}

No potential conflict of interest was reported by the authors.

\section{Funding}

This research was funded by the ERC MAPLE Consolidator Grant no. 682125. 


\section{Notes on contributors}

Tiago Silva is a post-doctoral researcher for the ERC MAPLE project at the Institute of Social Sciences, University of Lisbon. He holds a $\mathrm{PhD}$ in Political and Social Sciences from the European University Institute. His main research interests are political communication, online campaigning and European integration. [tiago.silva@ics.ulisboa.pt]

Yani Kartalis is a $\mathrm{PhD}$ candidate in Comparative Politics at the Institute of Social Sciences, University of Lisbon. He earned his MRes in Political Science at the Pompeu Fabra University in Barcelona. His research interests lie in the fields of political parties, political sociology and psychology, and automated data collection approaches for the social sciences. [eikartalis@campus.ul.pt]

Marina Costa Lobo (D.Phil, Oxford, Habilitation, Lisbon 2011) is Principal Researcher at the Institute of Social Sciences, University of Lisbon and vice-director of Instituto de Políticas Públicas (IPP). Currently, she is PI of the ERC Consolidator Project 'MAPLE', which researches the politicisation of Europe before and after the Eurozone crisis. She is the Director of the Portuguese Election Study and a member of the CSES Planning Committee. Her research interests include the role of leaders in electoral behaviour, economic voting and the consequences of EU politicisation. In 2021, she guest edited, together with Michael Lewis-Beck, a Special Issue in Electoral Studies on the topic of EU contestation and its effects on political behaviour. [marina.costalobo@ics.ul.pt]

\section{ORCID}

Tiago Silva (D) http://orcid.org/0000-0002-3835-9735

Yani Kartalis (D) http://orcid.org/0000-0002-7006-7978

Marina Costa Lobo (D) http://orcid.org/0000-0002-7329-0972

\section{References}

Araújo, Matheus, Julio Reis, Adriano Pereira, and Fabrício Benevenuto (2016). 'An Evaluation of Machine Translation for Multilingual Sentence-Level Sentiment Analysis', in Proceedings of the 31st Annual ACM Symposium on Applied Computing, SAC '16, 1140-5.

Aslerasouli, Parisa, and Gholam R. Abbasian (2015). 'Comparison of Google Online Translation and Human Translation with Regard to Soft vs. Hard Science Texts', Journal of Applied Linguistics and Language Research, 2:3, 169-84.

Boomgaarden, Hajo G., Rens Vliegenthart, Claes H. de Vreese, and Andreas R. T. Schuck (2010). 'News on the Move: Exogenous Events and News Coverage of the European Union', Journal of European Public Policy, 17:4, 506-26.

Börzel, Tanja (2005). 'Mind the Gap! European Integration between Level and Scope', Journal of European Public Policy, 12:2, 217-36.

Braun, Daniela, Sebastian Popa, and Hermann Schmitt (2019). 'Responding to the Crisis: Eurosceptic Parties of the Left and Right and Their Changing Position towards the European Union', European Journal of Political Research, $58: 3,797-819$.

Burscher, Björn, Daan Odijk, Rens Vliegenthart, Maarten de Rijke, and Claes H. de Vreese (2014). 'Teaching the Computer to Code Frames in News: 
Comparing Two Supervised Machine Learning Approaches to Frame Analysis', Communication Methods and Measures, 8:3, 190-206.

Ceron, Andrea, Luigi Curini, and Stefano M. Iacus (2016). 'First-and Second-Level Agenda Setting in the Twittersphere: An Application to the Italian Political Debate', Journal of Information Technology \& Politics, 13:2, 159-74.

de Vreese, Claes H. (2003). Framing Europe: Television News and European Integration. Amsterdam: Aksant.

de Vreese, Claes H., Susan A. Banducci, Holli A. Semetko, and Hajo G. Boomgaarden (2006). 'The News Coverage of the 2004 European Parliamentary Election Campaign in 25 Countries', European Union Politics, 7:4, 477-504.

De Vries, Catherine E. (2007). 'Sleeping Giant: Fact or Fairytale? How European Integration Affects National Elections', European Union Politics, 8:3, 363-85.

De Vries, Catherine E. (2018). Euroscepticism and the Future of European Integration. Oxford: Oxford University Press.

De Vries, Erik, Martijn Schoonvelde, and Gijs Schumacher (2018). 'No Longer Lost in Translation: Evidence That Google Translate Works for Comparative Bag-of-Words Text Applications', Political Analysis, 26:4, 417-30.

de Wilde, Pieter (2011). 'No Polity for Old Politics? A Framework for Analyzing the Politicization of European Integration', Journal of European Integration, 33:5, 559-75.

de Wilde, Pieter, Anna Leupold, and Henning Schmidtke (2016). 'Introduction: The Differentiated Politicisation of European Governance', West European Politics, 39:1, 3-22.

de Wilde, Pieter, and Christopher Lord (2016). 'Assessing Actually-Existing Trajectories of EU Politicisation', West European Politics, 39:1, 145-63.

de Wilde, Pieter, and Michael Zürn (2012). 'Can the Politicization of European Integration Be Reversed?', Journal of Common Market Studies, 50, 137-53.

Dutceac Segesten, Anamaria, and Michael Bossetta (2019). 'Can Euroscepticism Contribute to a European Public Sphere? The Europeanization of Media Discourses on Euroscepticism across Six Countries', Journal of Common Market Studies, 57:5, 1051-70.

Flesher Fominaya, Cristina, and Laurence Cox, eds. (2013). Understanding European Movements: New Social Movements, Global Justice Struggles, Anti-Austerity Protest. London: Routledge.

Glavaš, Goran, Nanni Federico, and Simone Paolo Ponzetto (2017). 'Unsupervised Cross-Lingual Scaling of Political Texts', in Proceedings of the 15th Conference of the European Chapter of the Association for Computational Linguistics, 2, 688-93.

Goldberg, Andreas C., Erika J. van Elsas, and Claes H. de Vreese (2020). 'Mismatch? Comparing Elite and Citizen Polarisation on EU Issues across Four Countries', Journal of European Public Policy, 27:2, 310-28.

Grande, Edgar, and Swen Hutter (2016a). 'Beyond Authority Transfer: Explaining the Politicisation of Europe', West European Politics, 39:1, 23-43.

Grande, Edgar, and Swen Hutter (2016b). 'The Politicisation of Europe in Public Debates on Major Integration Steps', in Swen Hutter, Edgar Grande, and Hanspeter Kriesi (eds.), Politicising Europe: Integration and Mass Politics. Cambridge: Cambridge University Press, 63-89.

Green-Pedersen, Christoffer (2012). 'A Giant Fast Asleep? Party Incentives and Politicisation of European Integration', Political Studies, 60:1, 115-30.

Hepp, Andreas, Elsler Monika, Lingenberg Swantje, Mollen Anne, Möller Johanna, Offerhaus Anke, Sword Keith, and Dimitry V. Pospielovsky (2016). The 
Communicative Construction of Europe: Cultures of Political Discourse, Public Sphere, and the Euro Crisis. London: Palgrave Macmillan.

Höglinger, Dominic (2016). Politicizing European Integration - Struggling with the Awakening Giant. New York: Palgrave Macmillan.

Hooghe, Liesbet, and Gary Marks (2009). 'A Postfunctionalist Theory of European Integration: From Permissive Consensus to Constraining Dissensus', British Journal of Political Science, 39:1, 1-23.

Hooghe, Liesbet, and Gary Marks (2018). 'Cleavage Theory Meets Europe's Crises: Lipset, Rokkan and the Transnational Cleavage', Journal of European Public Policy, 25:1, 109-35.

$\mathrm{Hu}$, Minqing, and Bing Liu (2004). 'Mining and Summarizing Customer Reviews', in Proceedings of the Tenth ACM SIGKDD International Conference on Knowledge Discovery and Data Mining, Seattle, 168-77.

Hutter, Swen, and Edgar Grande (2014). 'Politicizing Europe in the National Electoral Arena: A Comparative Analysis of Five West European Countries, 1970-2010', Journal of Common Market Studies, 52:5, 1002-18.

Hutter, Swen, Edgar Grande, and Hanspeter Kriesi, eds. (2016). Politicizing Europe: Integration and Mass Politics. Cambridge: Cambridge University Press.

Hutter, Swen, and Hanspeter Kriesi (2019). 'Politicizing Europe in Times of Crisis', Journal of European Public Policy, 26:7, 996-1017.

Imig, Doug (2002). 'Contestation in the Streets: European Protest and the Emerging Euro-Polity', Comparative Political Studies, 35:8, 914-33.

Kevin, Deirdre (2003). Europe in the Media: A Comparison of Reporting, Representation, and Rhetoric in National Media Systems in Europe. Mahwah, NJ: Lawrence Erlbaum Associates.

Kleinen-von Königslöw, Katharina (2012). 'Europe in Crisis? Testing the Stability and Explanatory Factors of the Europeanization of National Public Spheres', International Communication Gazette, 74:5, 443-63.

Koopmans, Ruud, and Jessica Erbe (2004). 'Towards a European Public Sphere? Vertical and Horizontal Dimensions of Europeanized Political Communication', Innovation: The European Journal of Social Science Research, 17:2, 97-118.

Kriesi, Hanspeter (2016). 'The Politicisation of European Integration', Journal of Common Market Studies, 54:1, 32-47.

Leupold, Anna (2016). 'A Structural Approach to Politicisation in the Euro Crisis', West European Politics, 39:1, 84-103.

Lippmann, Walter (1922). Public Opinion. New York: Macmillan.

Lobo, Marina, and Roberto Pannico (2020). 'Increased Economic Salience or Blurring of Responsibility? Economic Voting during the Great Recession', Electoral Studies, 65:5, 102141.

Lucas, Christopher, Richard Nielsen, Margaret Roberts, Brandon Stewart, Alex Storer, and Dustin Tingley (2015). 'Computer-Assisted Text Analysis for Comparative Politics', Political Analysis, 23:2, 254-77.

Maier, Michaela, Adam Silke, Claes H. De Vreese, Melanie Leidecker-Sandmann, Beatrice Eugster, Franzisca Schmidt, and Eva Antl-Wittenberg (2014). 'Politicization of EU Integration. Codebook for a Content Analysis of Media and Party Communication', available at http://www.ikmb.unibe.ch/codebuch_ eu2014 (accessed 6 April 2021).

Mair, Peter (2000). 'The Limited Impact of Europe on National Party Systems', West European Politics, 23:4, 27-51. 
Marks, Gary, and Marco R. Steenbergen, eds. (2004). European Integration and Political Conflict. Cambridge: Cambridge University Press.

Mohammed, Saif M., and Peter D. Turney (2010). 'Emotions Evoked by Common Words and Phrases: Using Mechanical Turk to Create an Emotion Lexicon', in Proceedings of the NAACL HLT 2010 Workshop on Computational Approaches to Analysis and Generation of Emotion in Text, 26-34.

Nielsen, Finn (2011). 'A New ANEW: Evaluation of a Word List for Sentiment Analysis in Microblogs', arXiv preprint. arXiv: 1103.2903.

Nord, Lars, and Jesper Strömbäck (2006). 'Game Is the Name of the Frame: European Parliamentary Elections in Swedish Media 1995-2004', in Michaela Maier and Jens Tenscher (eds.), Campaigning in Europe-Campaigning for Europe. London: LIT Publishers, 191-206.

Norris, Pippa (2000). A Virtuous Circle: Political Communications in Postindustrial Societies. Cambridge: Cambridge University Press.

Orriols, Lluis, and Guillermo Cordero (2016). 'The Breakdown of the Spanish Two-Party System: The Upsurge of Podemos and Ciudadanos in the 2015 General Election', South European Society and Politics, 21:4, 469-92.

Pang, Bo, and Lillian Lee (2008). 'Opinion Mining and Sentiment Analysis', Foundations and Trends in Information Retrieval, 2:1-2, 1-135.

Peter, Jochen, and Claes H. de Vreese (2004). 'In Search of Europe: A Cross National Comparative Study of the European Union in National Television News', Harvard International Journal of Press/Politics, 9:4, 3-24.

Pfetsch, Barbara (1996). 'Convergence through Privatization? Changing Media Environments and Televised Politics in Germany', European Journal of Communication, 11:4, 427-51.

Pfetsch, Barbara, Silke Adam, and Barbara Eschner (2008). 'The Contribution of the Press to Europeanization of Public Debates: A Comparative Study of Issue Salience and Conflict Lines of European Integration', Journalism: Theory, Practice \& Criticism, 9:4, 465-92.

Picard, Robert G., ed. (2015). The Euro Crisis in the Media: Journalistic Coverage of Economic Crisis and European Institutions. London: B. Tauris.

Popescu, Marina, Toka Gabor, Gosselin Tania, and Jose Santana Pereira (2011). European Media Systems Survey 2010: Results and Documentation. Essex: European Media Systems Survey.

Proksch, Sven-Oliver, Will Lowe, Jens Wäckerle, and Stuart Soroka (2019). 'Multilingual Sentiment Analysis: A New Approach to Measuring Conflict in Legislative Speeches', Legislative Studies Quarterly, 44:1, 97-131.

Rinker, Tyler (2019). 'Package 'Sentimentr', available at: https://cran.r-project. org/web/packages/sentimentr/sentimentr.pdf (accessed 6 April 2021).

Risse, Thomas (2010). A Community of Europeans? Transnational Identities and Public Spheres. Ithaca, NY: Cornell University Press.

Schimmelfennig, Frank (2014). 'European Integration in the Euro Crisis: The Limits of Post-Functionalism', Journal of European Integration, 36:3, 321-37.

Schmidtke, Henning (2016). 'The Differentiated Politicisation of European Tax Governance', West European Politics, 39:1, 64-83.

Schmitter, Philippe (1969). 'Three Neo-Functional Hypotheses about International Integration', International Organization, 23:1, 161-6.

Senninger, Roman, and Markus Wagner (2015). 'Political Parties and the EU in National Election Campaigns: Who Talks about Europe, and How?', Journal of Common Market Studies, 53:6, 1336-51. 
Soroka, Stuart, Lori Young, and Meital Balmas (2015). 'Bad News or Mad News? Sentiment Scoring of Negativity, Fear, and Anger in News Content', The ANNALS of the American Academy of Political and Social Science, 659:1, 108-21.

Statham, Paul (2007). 'Journalists as Commentators on European Politics: Educators, Partisans or Ideologues?', European Journal of Communication, 22:4, 461-77.

Statham, Paul, and Hans-Jörg Trenz (2013). The Politicization of Europe: Contesting the Constitution in the Mass Media. Abingdon: Routledge.

Swanson, David L., and Paolo Mancini (1996). 'Patterns of Modern Electoral Campaigning and their Consequences', in David L. Swanson and Paolo Mancini (eds.), Politics, Media, and Modern Democracy: An International Study of Innovations in Electoral Campaigning and their Consequences. London: Praeger, 247-76.

Tausczik, Yla R., and James W. Pennebaker (2010). 'The Psychological Meaning of Words: LIWC and Computerized Text Analysis Methods', Journal of Language and Social Psychology, 29:1, 24-54.

Young, Lori, and Stuart Soroka (2012). 'Affective News: The Automated Coding of Sentiment in Political Texts', Political Communication, 29:2, 205-31.

Zürn, Michael (2016). 'Opening up Europe: Next Steps in Politicisation Research', West European Politics, 39:1, 164-82. 